\title{
Ecology of Triatoma rubrovaria (Hemiptera, Triatominae) in Wild and Peridomestic Environments of Uruguay
}

\author{
Roberto Salvatella, Raquel Rosa, Yester Basmadjian, Andres Puime, Luis \\ Calegari, Jorge Guerrero, María Martinez, Gabriela Mendaro, Daniel Briano*,

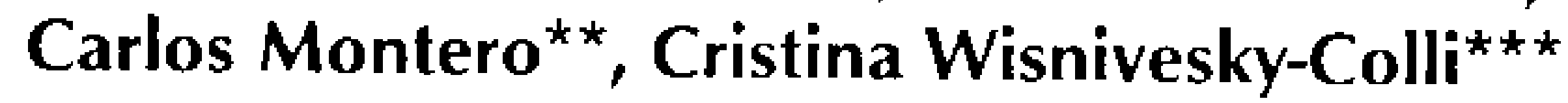

\begin{abstract}
Departamento de Parasitologia/Unidad de Biologia Parasitaria, Instituto de Higiene, Universidad de la República, Av. A. Navarto 3051, CP 11600, Montevideo, Unuguay ${ }^{\star}$ Departamento de Higiene, Municipalidad de Rivera

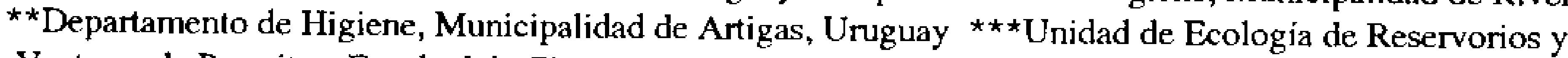
Vectores de Parasitos, Facultad de Ciencias Exactas y Naturales, Universidad de Buenos Aires, Argentina
\end{abstract}

This paper describes population structure, spatial distribution and habitat selection of wild and peridomestic populations of Triatoma rubrovaria (Blanchard,1843). Field studies were carried out at Las Piedras and La Bolsa in the Northern Department of Artigas, Uruguay. A semicircular sampling area, divided in seven or eight triangular sectors was sequentially examined from October 1990 to November 199I. At Las Piedras (typical wild habitat) $1063 \mathrm{~T}$. rubrovaria bugs were colected from $84 \%$ of the rocky outcroops ("pedregales"). Abundance varied by season peaking in October-November (spring). Throughout the year, most of the population was made up of third, fourth and fifth instar nymphs; adults were found from October to March. In the peridomestic environment of La Bolsa, however T. rubrovaria was less common and showed a more irregular instar distribution. Colonized ecotopes, were those close to houses. In both sites T. rubrovaria was mainly associated with the geckonid Homonota uruguayensis and the cockroach Blaptica dubia.

Key words: Triatoma rubrovaria - triatomines - Uruguay - ecology

Triatoma rubrovaria (Blanchard) (Hemiptera, Reduviidae) was first described as Conorhinus rubrovarius in 1843 , from specimens collected at Maldonado, Unuguay (Lent 1942). Its distribution covers parts of northeastern Argentine, Southern Brazil and Uruguay (Lent \& Wygodzinsk 1979) where it is often found amongst outcorps of rocks ("pedregales"). In Uruguay, T. rubrovaria sustains the enzootic cycle of Trypanosoma cruzi (Salvatella 1986) and is commonly found in the peridomestic habitats, wherever pedregales are close to human habitations and/or people use rocks to construct fences. Moreover recent observations from Rio Grande do Sul (Silveira et al. 1984) and the Northem Departaments of Rivera and Artigas in Unuguay, (Salvatella et al. 1991) detected indoor colonies in houses of different construction types. $T$. rubrovaria may therefore assume greater importance in domestic transmission of $T$. cruzi, especially where the main do-

Projects: Ecologia de Vectores. Enfermedad de Chagas. $02 / 004 / 106 / 90$ y 91 . Universidad de la Republica. CSIC. Unuguay. CEE. TS3*-CT91-0029

Received 8 June 1994

Accepted 23 January 1995 mestic vector, $T$. infestans has been controlled by insecticide spraying.

This paper describes the habitat, espacial distribution and population structure of wild and peridomestic populations of $T$. rubrovaria from Northern Uruguay.

\section{MATERIALS AND METHODS}

Two rural sites, Las Piedras and La Bolsa located in the Departament of Artigas, near the Brazilian border were chosen for this study (Fig. 1). Criteria selection were: (a) frequent presence of $T$. rubrovaria populations and (b) contrasting features of the two areas: Las Piedras represented a typical wild habitat and La Bolsa met the conditions promoting peridomestic invasion of bugs from nearby rocky outcrops.

The semicircular sampling area was divided in seven or eight triangular sectors of $200 \times 100 \mathrm{~m}$ each, that were further subdivided every $50 \mathrm{~m}$. In Las Piedras, the landscape of basaltic outcrops scattered in the prairie was fairly homogeneous and the sampling area was centered on an elevated point (Fig. 2). In La Bolsa, the centre was a house surrounded by a complex peridomestic area with several outdoor premises: storeroom, stone fenced corrals, chicken coop. Neighbouring dwellings were also included in the sampling area (Fig. 3). 


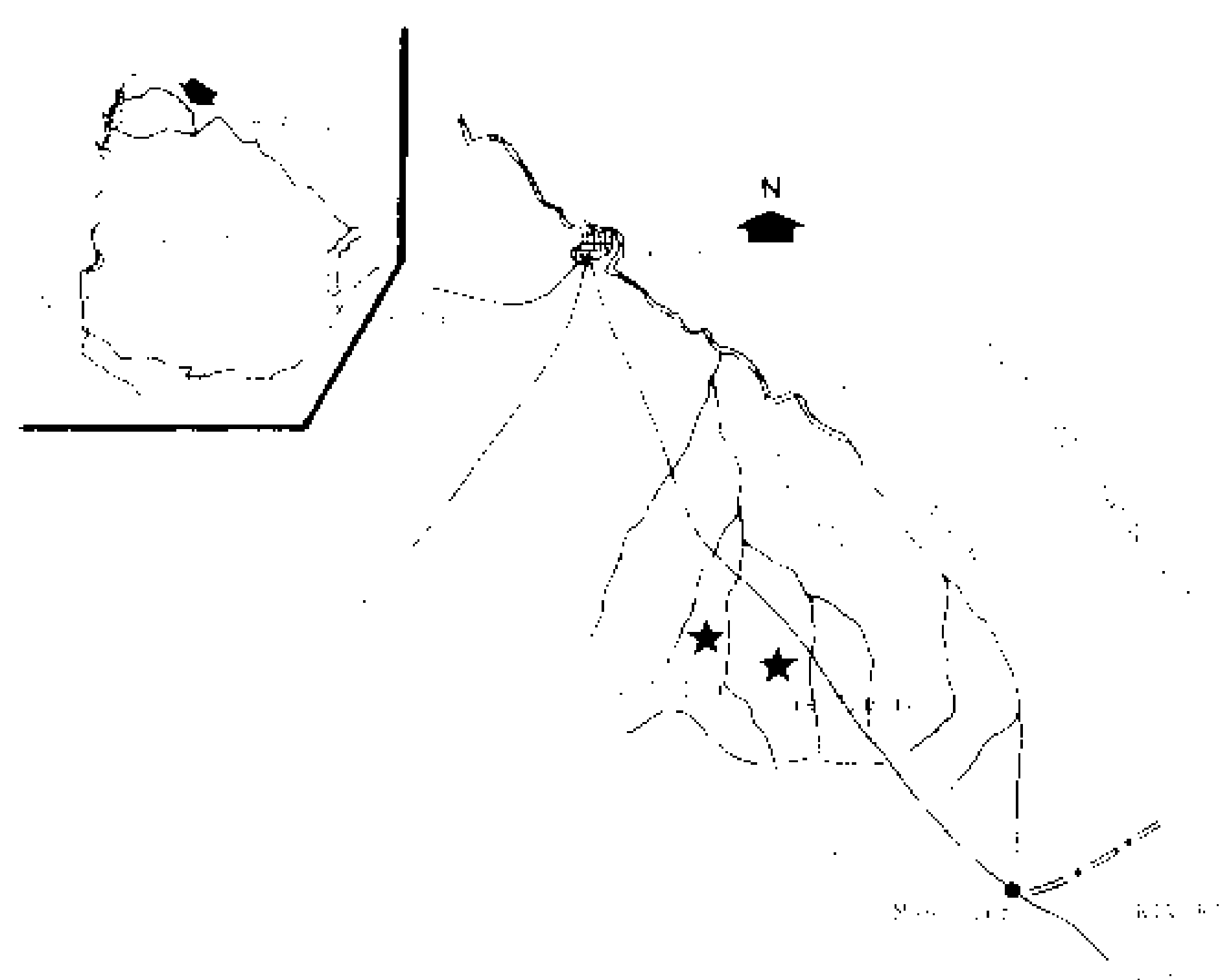

I.ig. 1: A - Map of Uruguay, Department of Artigas in dotled lines. B - Area of the Departament of Artigas with lexation of study areas: Las Piedras and I a Bolsa.

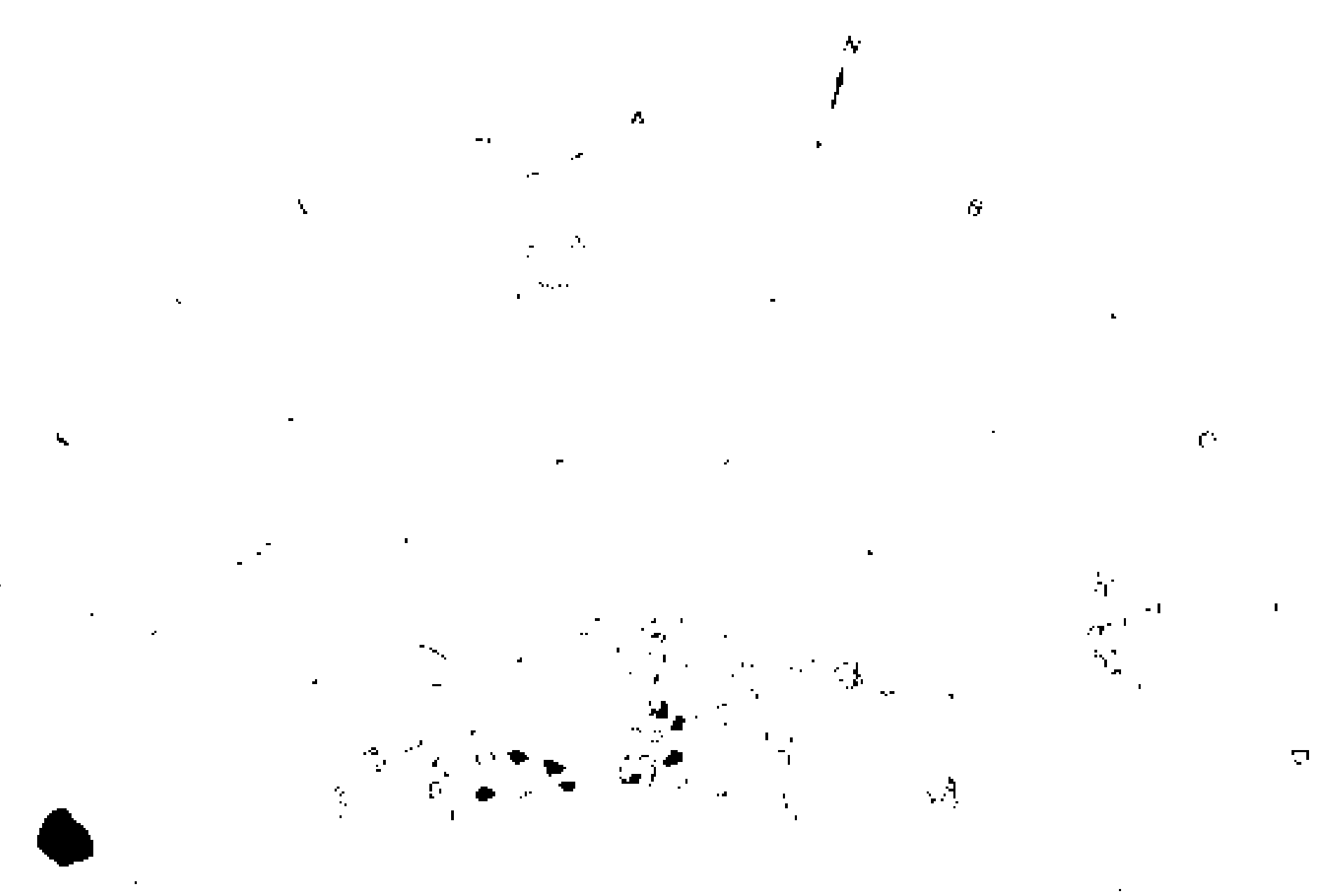

Fig. 2: scheme of sampling sectors at "Las Piedras", wild natural environment. Natural stone grounds are drawn: white infested; black non infested.

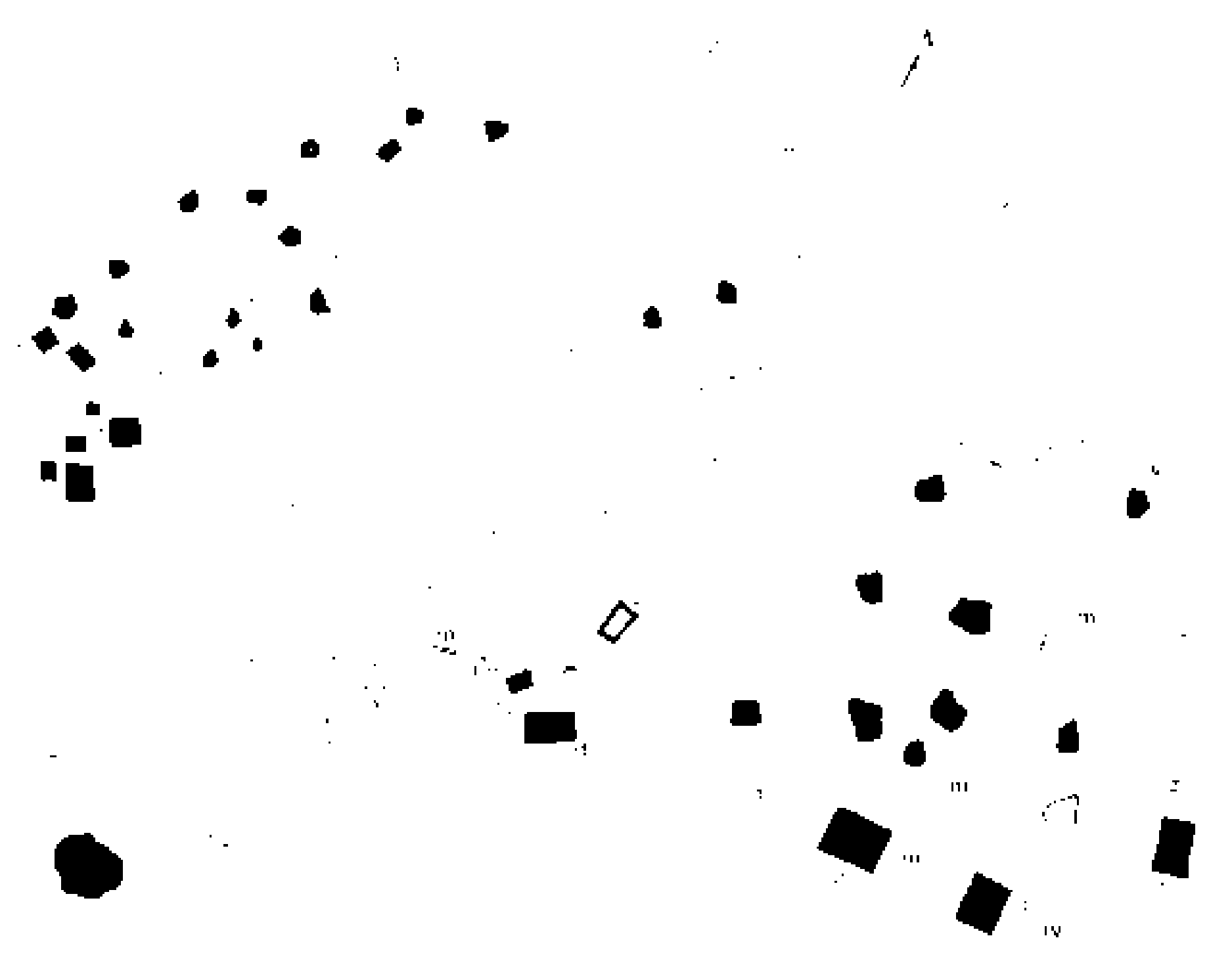

Fig. 3: scheme of sampling sectors at "I a Bolsi", numal area with peridomestic environment. D: domiciles. C: stone yards. $\mathrm{M}$ : stone walls. $\mathrm{G}$ : henhouses. The rest are stonegrounds (untouched or moxtified) and piled stones.
At La Bolsa, the triangular sectoors were sequentialy examined in October and November 1990, January, March, May, June, October and November 1991. In Las Piedras, observations were made on the same dates, except for October 1991 when the area was inaccessible due to climatic conditions.

All ecotopes suitable for $T$. rubrovaria were first recorded on a diagram, and then thoroughly examined. Pedregales were dismantled and peridomestic structures and dwellings sampled by timed manual collection (Wisnivesky-Colli et al. 1987).

\section{RESULTS}

Las Piedras - A total of 58 pedregales suitable to shelter $T$. rubrovaria were identified in the seven sections examined and $84 \%$ were colonized (Table I). Suitable ecotopes were those made up by overlapping flat stones on dry soil. Those sectors examined in May and June had few pedregales, but all harboured triatomines.

At total $1063 \mathrm{~T}$. rubrovaria was collected of which 978 (92\%) were nymphs (Table I). Abundance varied by season, eaking in October-November (spring). Throughout the year, more than $60 \%$ of the population was made up by third, fourth and fifth instar nymphs. The latter predominated in winter simples. Adults were found from October to March, males appeared before but females disappeared later.

Animals found with the $T$. rubrovaria colonies were as follows: vertebrates: Homonota uruguayensis (Vaz-Ferreira \& Sierra) gekonid lizard (in 32 ecotopes, $65 \%$ of total colonized pedregales), Tupinambis teguixin (L.) iguana (in four ecotopes, 8\% of the total), Leptotyphlops mumosi Orejas-Miranda apodous saurian (in two ecotopes, $4 \%$ of the total), Laptodacty/hs mistocimas (Cope) frog (in one ecotope, $2 \%$ of the total), Didelphis albiventris (Temminck) opossum (in one ecotope, $2 \%$ of total), Tropidurus sp. iguana (in one ecotope, $2 \mathscr{x}$ of the total); invertebrates: Blaptica dubia (Serville) cockroach (in 29) ecotopes, 59\% of the total), Grillus sp. cricket (in nine ecotopes, $18 \%$ of total), Zelurus sp. predatory bug (in three ecotopes, $6 \%$ of total), Triatoma circummaculata (Stal, 1859) triatomine, (in three ecotopes, $6 \%$ of the total), termite (in two ecotopes, $4 \%$ of the total). There were also Bothriurus bonaerensis (Koch) scorpion, Gramostola sp. spider, butterfly larva and miriapod, each one of those in one ecotope.

La Bolsa - Habitat heterogeneity was the principal feature of the peridomestic sampling area at La Bolsa (Fig.3). Examined ecotopes included: natural stonegrounds (pedregales), either untouched or modified by stone extraction, stones piled after field clearing (stone heaps), 
stone walls, stone fences of yards, henhouses, piled bricks, storerooms and houses.

A total of 67 ecotopes suitable to shelter $T$. rubrovaria was identified in the eight sections examined, and 32 were colonized (Table II). Searching of 11 man made structures, excluding yards, rendered three $T$. rubrovaria nymphs found in two henhouses located close to stone walls.

A total of 291 bugs was captured of which, $91 \%$ were nymphs. Adults were found only in October and November; eight males in 1990 and nine males and five females in 1991. Instar distribution of bugs in pedregales differed from those at Las Piedras, frequent some instars were about and there was not a progressive sequence of stages. Table II shows the proportion of different ecotopes that were infested, as well as the median number and range of T.rubrovaria bugs found in each one. Stone walls and yards were the most heavily infested.

Animals cohabiting with $T$. rubrovaria in pedregales at La Bolsa were as follows: vertebrates: H.uruguayensis (in eight ecotopes, $25 \%$ of the total), chicken (in five ecotopes, $16 \%$ of the total), Didelphis albiventris opossum (in two ecotopes, $6 \%$ of total), cricetid rodents (in two ecotopes, $6 \%$ of the total); invertebrates: $B . d u$ bia cockroach (in 18 ecotopes, $56 \%$ of the total), Strophocheilus sp. terrestrial snail (in six ecotopes, $19 \%$ of total), Lycosa raptoria (Walkenaer) spider (in five ecotopes, $16 \%$ of total), Gramostola mollicoma (Ausserer) spider (in two ecotopes, $6 \%$ of total), Segestria ruficeps Guerin spider, toghether with butterfly larva, termite and miriapod, each one of those in one ecotope. As in Las Piedras, the lizard $H$. uruguayensis and the cockroach $B$. dubia predominated, but overall were fewer wild associated vertebrates.

\section{TABLE I}

Colonized ecotopes and Triatoma rubrovaria bugs collected in natural stonegrounds at Las Piedras, Department of Artigas, Uruguay (October 1990-November 1991)

\begin{tabular}{|c|c|c|c|c|c|c|c|}
\hline \multirow[t]{2}{*}{ Date } & \multirow[t]{2}{*}{ Section } & \multirow[t]{2}{*}{$\mathrm{A}^{a}$} & \multirow[t]{2}{*}{ Nymphs } & \multicolumn{2}{|c|}{ Adults } & \multirow{2}{*}{$\begin{array}{c}\text { Adults } \\
\text { Total }\end{array}$} & \multirow[b]{2}{*}{ Total } \\
\hline & & & & $\mathbf{M}$ & $\mathbf{F}$ & & \\
\hline Oct. 90 & A & $8 / 8$ & 469 & 42 & 9 & 51 & 520 \\
\hline Nov. 90 & B & $10 / 13$ & 81 & 4 & 4 & 8 & 89 \\
\hline Jan. 91 & C & $10 / 11$ & 88 & 1 & 2 & 3 & 91 \\
\hline Mar. 91 & D & $6 / 6$ & 34 & - & 2 & 2 & 36 \\
\hline May 91 & $\mathrm{E}$ & $2 / 2$ & 24 & - & - & - & 24 \\
\hline Jun. 91 & F & $4 / 4$ & 133 & - & - & & 133 \\
\hline Nov. 91 & H & $9 / 14$ & 149 & 9 & 12 & 21 & 170 \\
\hline Total & - & $49 / 58$ & 978 & 56 & 29 & 85 & 1063 \\
\hline
\end{tabular}

: No. positive ecotopes/Total ecotopes examined; $M$ : males; F: females.

TABLE II

Infested ecotopes and median density of Triatoma rubrovaria in La Bolsa, Department of Artigas, Uruguay (October 1990-November 1991)

\begin{tabular}{lccc}
\hline & $\begin{array}{c}\text { No. } \\
\text { examined }\end{array}$ & $\begin{array}{c}\text { No. } \\
\text { positive (\%) }\end{array}$ & $\begin{array}{c}\text { Median bug } \\
\text { density } \\
\text { (range) }\end{array}$ \\
\hline Stone walls and stone yards & 8 & $7(88)$ & $19(8-33)$ \\
Natural altered stonegrounds & 8 & $3(38)$ & $3(1-9)$ \\
Stone heaps & 38 & $18(47)$ & $6(1-29)$ \\
Houses and peridomestic premises & 11 & $2(18)$ & $2(2)$ \\
Natural stonegrounds (untouched) & 2 & $2(100)$ & $15(15)$ \\
\hline Total & 67 & $32(48)$ & $6(1-33)$ \\
\hline
\end{tabular}




\section{DISCUSSION}

Las Piedras represents the natural habitat for T. rubrovaria where big colonies develop in the extense pedregales of the prairie, especially in those located at the most elevated points. Suitability of this environment is shown by the high proportion of colonized ecotopes. Highest relative abundance was found in those pedregales formed by overlapping flat stones on dry soil that made up a laberinthic structure suitable to shelter vertebrates, including small mammals.

T. rubrovaria colonies showed the typical instar distribution already reported for other wild triatomine species, being predominantly immature stages (Forattini et al. 1977, WisniveskyColli 1993). Abundance was strongly correlated with climatic conditions, as reported for other silvatic triatomines (Rabinovich 1985). First instar nymphs were present all year around, although numbers increased in spring and summer. However adults were not collected from April to October and those few nymphs found in winter could be insects that hatched during late summer and experienced slower growth during the following winter. In the cold season fifth instar nymphs predominated, probably due to the higher resistance of older nymphs to adverse environmental conditions (Salvatella et al. unpublished data). Males appeared earlier than females, although females seemed to live longer.

In the peridomestic environment of La P slsa, T. rubrovaria colonized stone walls and stone fences. Colonized ecotopes were always those close to houses. Comparison of colony patterns between La Bolsa and Las Piedras suggest that human activity affects the development of $T$. rubrovaria, for example by extracting stones from natural pedregales by buming and clearing the fields, by planting trees, by piling up rubbish, and by raising domestic animals that may displace wild vertebrates. Peridomestic colonies showed an irregular instar distribution but the overall insect collection was smaller than in Las Piedras, in spite of the presence of abundant local food sources. In January 1991, only four bugs were caught in natural stonegrounds (sector C); these showed the characteristic pattern of suitable ecotopes but were shaded by cultivated Eucaliptussoces.

Association of $T$. rubrovaria with the geckonid $H$. uruguayensis and the cockroach $B$. dubia was common in both wild and peridomestic environments. This strongly suggested that those animals could have a trophic relationship with $T$. rubrovaria, a fact lately confirmed in our laboratory (Salvatella et al. unpublished data).

\section{REFERENCES}

Forattini OP, Santos JLF, Ferreira EO, Da Rocha e Silva EO, Rabello EX 1977. Aspéctos ecológicos da tripanossomiase americana. X. Dados populacionais das colônias de Pastrongylus megistus e de Triatoma sordida espontaneamente desenvolvidos em ecotopos artificiais. Rev de Saú Púb 11: 362-374.

Gorla DE, Schofield CJ 1989. Population dynamics of Triatoma infestans under natural climatic conditions in the Argentine Chaco. Med and Vet Entomol 3: 179-194.

Lent H 1942. Estudos sobre os triatomideos do Estado do Rio Grande do Sul, com descrição de uma espécie nova. Rev Brasil Biol 2: 219-231.

Lent $H$, Wygodzinsky $P^{\prime} 1979$. Revision of the triatominae (Hemiptera, Reduviidae) and their importance as vectors of Chagas' disease. Bull Am Mus Nat Hist 163: 522-524.

Osimani JJ 1959. Enfenmedad de Chagas: importante flagelo de las zonas rurales del Unuguay. Rev Goiana Med 5: 339-356.

Rabinovich JE 1985. Ecologia poblacional de los triatominos. In Factores biológicos y ecológicos en la Enfermedad de Chagas. OPS OMS I: 121-149.

Salvatella R 1990. La situación epidemiológica de la enfermedad de Chagas y su control en Uruguay. Intercambio 1: 3-8.

Salvatella R, Calegari L, Lowinger M, Basmadjián Y, Rosa R, Mendaro G, Civila E 1991. T. rubrovaria (Hemiptera, Triatominae) y su papel como vector secundario del ciclo domiciliario de T. cruzi en Unuguay. Rev Méd Uruguay 7: 45-50.

Silveira AC, Ramos. V, Borges R 1984. Distribuiçāo de triatomíneos capturados no ambiente domiciliar, no período 1975/83, Brasil. Rev Brasil Malariol D Trop 36: 15-312.

Wisnivesky-Colli C 1993. Triatominos vectores secundarios del Trypanosoma cruzi: su domiciliacion potencial. Talleres 3: Universidad de Los Andes, Merida, Venezuela, en prensa.

Wisnivesky-Colli C, Paulone I, Perez A, Chuit R, Gualtieri J, Solarz N, Smith A, Segura EL 1987. A new tool for continuous detection of the presence of triatomine bugs, vectors of Chagas' disease in rural households Medicina 47: 45-50. 